\section{КРУГЛЫЙ СТОЛ «ОКТЯБРЬСКАЯ РЕВОЛЮЦИЯ И ТУВА» (г. КЫЗЫЛ, 7 НОЯБРЯ 2017 г.)}

Наталия К.-К. Ховалыг, Тамара М. Шой-Сюрюн

Тувинский институт гуманитарных и прикладных социальноэкономических исследований, Российская Федерация

\section{"OCTOBER REVOLUTION AND TUVA": A ROUNDTABLE (KYZYL, 7 NOVEMBER 2017)}

В статье представлен обзор работы круглого стола «Октябрьская революция и Тува», приуроченного к 100-летию Октябрьской революции 1917 года, который прошел 7 ноября 2017 2. в Национальном музее им. Алдан Маадыр Республики Тыва в г. Кызыле (Россия). Организатором проведения круглого стола выступил Тувинский институт гуманитарных и прикладных социально-экономических исследований. В работе круглого стола приняли, помимо ученых, ветераны партии, депутаты Верховного Хурала (парламента) Республики Тыва, а также студенты Тувинского государственного университета, учащиеся школ 2. Кызыла.
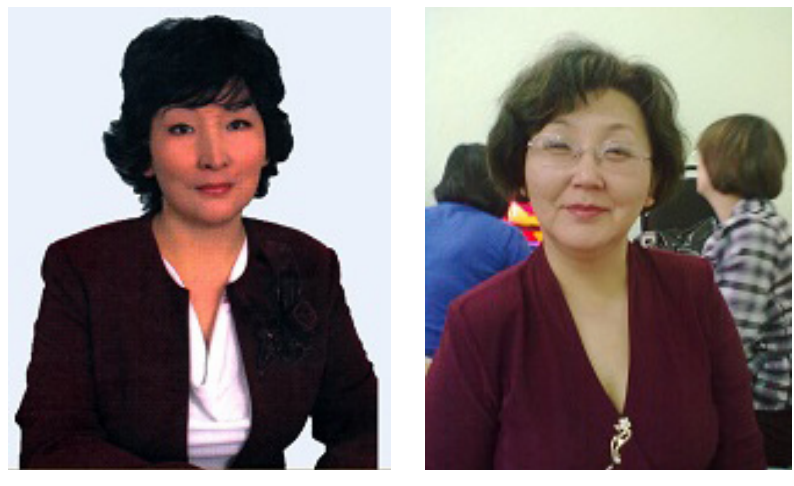

This is an overview of a roundtable which was held on November 7, 2017, at the Alan Maadyr National Museum of the Republic of Tuva, to mark the 100th an $n$ iversary of the October Revolution of 1917. The event was organized by the Tuvan Institute for the Humanities and Applied Social and Economic Studies. Among the roundtable's participants were scholars, Communist Party veterans, members of the Verkhovny Khural

Ховалыг Наталия Куске-Караевна - кандидат химических наук, ведущий научный сотрудник отдела маркетинга и коммуникаций Тувинского института гуманитарных и прикладных социальноэкономических исследований. Адрес: 667000, Россия, г. Кызыл, ул. Кочевато, д. 4. А. Тел.: +7 (39422) 2-39-36. Эл. адрес: nataliya-khovalyg@yandex.ru

Шой-Сюрюн Тамара Михайловна - маркетолог отдела маркетинга и коммуникаций Тувинского института гуманитарных и прикладных социально-экономических исследований. Адрес: 667000, Россия, г. Кызыл, ул. Кочетова, д. 4. Тел.: +7 (39422) 2-39-36. Эл. адрес: tamara1273@mail.ru

Hovalyg Natalia Kuske-Karayevna, Candidate of Chemistry, Lead Research Fellow, Department of Marketing and Communication, Tuva Institute for the Humanities and Applied Social and Economic Studies. Postal address: 4 Kochetov St., Kyzyl, Russian Federation 667000. Tel.: +7 (39422) 2-39-36. E-mail: nataliya-khovalyg@yandex.ru

Shoi-Syuryun Tamara Mikhailovna, Marketing manager, Department of Marketing and Communication, Tuva Institute for the Humanities and Applied Social and Economic Studies. Postal address: 4 Kochetov St., Kyzyl, Russian Federation 667000. Tel.: +7 (39422) 2-39-36. E-mail: tamara1273@mail.ru 
Обзор включает тезисы из докладов ученых, посвященных самым разным аспектам: политике, культуре, образованию Тувы в советское время. Даны выдержки из выступлений ветеранов труда - живых свидетелей советского периода истории Тувы, которые оценивали значение революции и советских преобразований сквозь призму своих личных судеб. Их отцы и они сами никогда не смогли бы добиться жизненных успехов, считают они, не смогли бы построить так много в Туве, если бы не Советская власть.

Самым важным результатом научного и общественно-политического собрания республики стало выражение общего мнения: Великая Октябрьская революция 1917 года, которая произошла в России, повлияла самым непосредственным образом и в позитивном смысле на развитие Тувы, стала фактором дальнейшего слияния исторических судеб маленькой республики и северной державы.

Ключевые слова: круглый стол; обзор; Великая Октябрьская революция, революция 1917 года; Тува; история Тувы; Россия и Тува; советская история
(Tuva's parliament), and students of Tuvan State University and of Kyzyl's secondary schools.

This overview covers the main points of the scholarly papers devoted to various aspects of Tuva's Soviet-time experience - its politics, culture, education, etc. 'Veterans of labor', eyewitnesses of this period, put the significance of the Revolution and subsequent transformations in the context of their own lives. They believe that their parents and themselves would never have achieved any success and would never have been able to do as much as they did, without the establishment of the Soviet power in the region.

The roundtable participants, representing the scholarly and political consensus in the region, agreed that the Great October Revolution of 1917 in Russia had a most direct and positive impact on the development of Tuva, tying the small republic and the great Northern power ever closer to each other.

Keywords: roundtable; overview; Great October revolution; 1917 revolution; Tuva; history of Tuva; Russia and Tuva; Soviet history

\section{Введение}

Тувинский институт гуманитарных и прикладных социально-экономических исследований 7 ноября 2017 г. провел в конференц-зале Национального музея им. Алдан Маадыр Республики Тыва круглый стол на тему «Октябрьская революция и Тува», приуроченный к 100-летию Октябрьской революции 1917 г. В работе круглого стола приняли участие ученые-тувиноведы, а также ветераны партии, депутаты Верховного Хурала (парламента) Республики Тыва, студенты Тувинского государственного университета, учащиеся школ г. Кызыла.

Модератором круглого стола выступила директор Тувинского института гуманитарных и прикладных социально-экономических исследований, кандидат исторических наук Марианна Монге-Байыровна Харунова.

\section{История глазами ветеранов}

Работу круглого стола открыло выступление директора Национального музея им. Алдан Маадыр Республики Тыва, доктора филологических наук Каадыроола Алексеевича Бичелдея. Он отметил, что к Октябрьской революции 1917 г. можно относиться по-разному, но необходимо понять одно: она - неотъемлемая часть непрерывной великой истории нашей страны. История не существует 


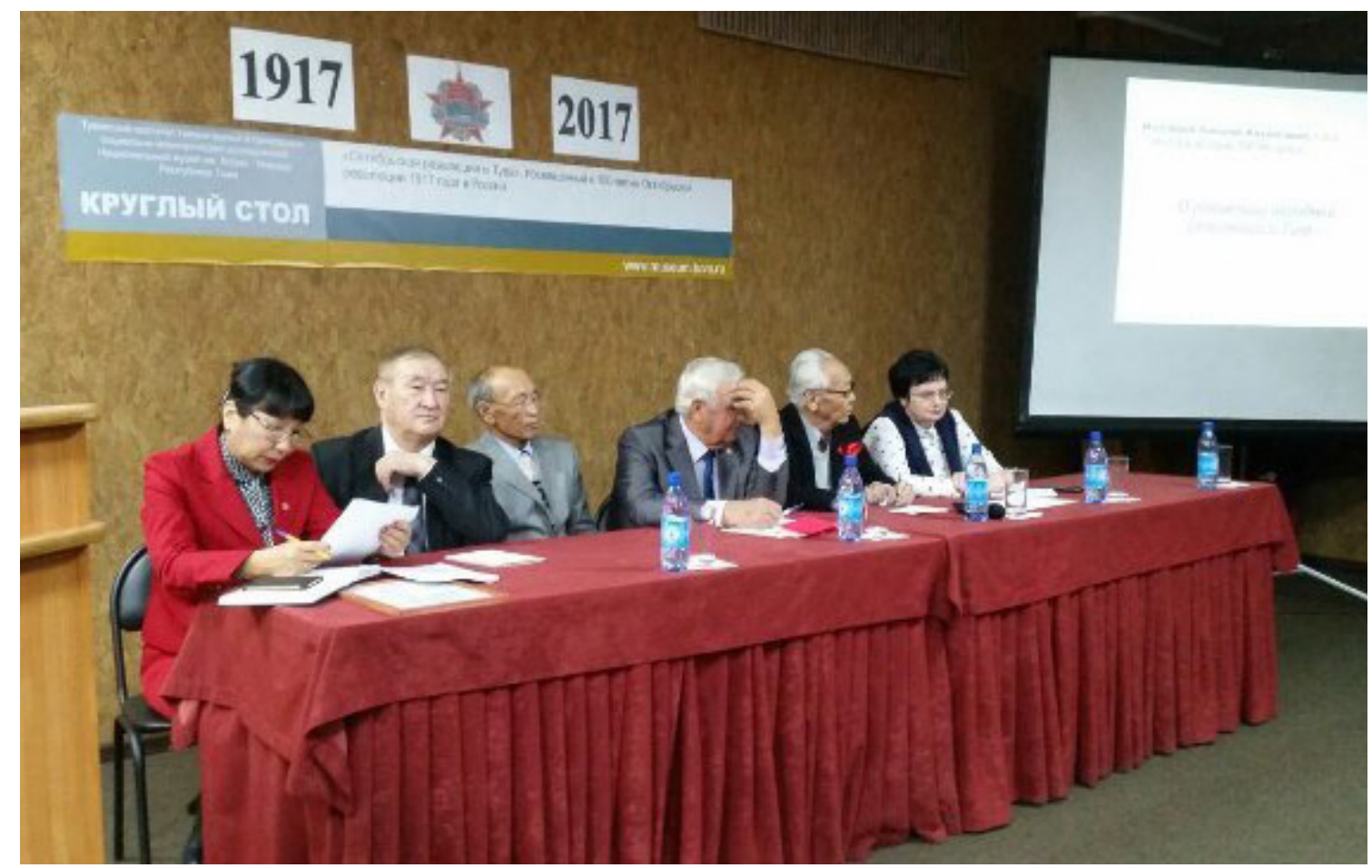

сама по себе, ее делают конкретные люди, живущие в тот или иной период времени. Огромное количество граждан Российской Федерации, стран Содружества независимых государств и других государств мира достойно жили и трудились в СССР. Среди них, как указал директор музея, присутствовавшие в зале Григорий Чоодуевич Ширшин, первый секретарь Тувинского республиканского комитета КПСС (1973-1990), Дандар-оол Кок-Хунааевич Ооржак - первый секретарь Тандинского райкома партии, председатель Комитета народного контроля Тувинской АССР, председатель Палаты представителей Великого Хурала Республики Тыва, Иван Васильевич Чучев, награжденный Орденом Ленина, Герой Социалистического труда, дважды удостоенный премии им. Столыпина, а также награжденный медалью Республики Тыва «За доблестный труд», Орденом Республики Тыва и др.

С искренней благодарностью за проведение такого значимого мероприятия выступил кандидат исторических наук, ветеран Коммунистической партии Алдын-оол Кангаевич Канзай. Он остановился на значении Великой Октябрьской революции для Тувы, очернить которое, по его мнению, невозможно. Малочисленный тувинский народ обрел свое государство - Тувинскую Народную Республику (ТНР) - только благодаря Октябрьской революции. Именно тогда и после этого, в течение XX века, до неузнаваемости изменился облик тувинской земли: были построены города, появились школы, детские сады и больницы. Каждое сельское поселение, каждая чабанская стоянка получили энергоснабжение. По размаху и темпам развития Тува в советское время совершила прорыв. В Туве каждый человек был занят, рабочих рук не хватало. 
Ирина Петровна Самойленко, заместитель Председателя Верховного Хурала (парламента) Республики Тыва, поздравила участников круглого стола с великим праздником. «Молодежь должна знать историю и вклад ветеранов в развитие Тувы», - высказалась она.

Хонук-оол Доржуевич Монгуш, председатель Общественной палаты Республики Тыва, в своем выступлении обратил внимание участников круглого стола на то, что Октябрьскую революцию в Туве поддержали самые низшие слои населения. За годы Советской власти уровень жизни в Туве поднялся в четыре раза. Такого рывка в жизни тувинского народа не было. От себя лично и от имени всех присутствовавших в зале он выразил огромную благодарность ветеранам за тот трудовой подвиг, который они совершили в советские годы в деле развития народного хозяйства Тувы.

Биче-оол Анинович Амарда, ветеран партии, сказал, что только благодаря Октябрьской революции он - простой рабочий - был избран в Верховный Совет СССР, в Центральный комитет коммунистической партии Советского Союза. Для него счастьем было вместе со всеми жителями Тувы под руководством Салчака Калбакхорековича Тока, Григория Чоодуевича Ширшина, а также вместе с присутствовавшими в этом зале Алдын-оолом Кангаевичем Канзайем, Дандароолом Кок-Хунаевичем Ооржаком, Иваном Васильевичем Чучевым - работать на развитие Тувы, строить новые города такие, как Ак-Довурак, поселок ХовуАксы, комбинаты Туваасбест и Тувакобальт. Он также высказался, что именно Октябрьская революция дала толчок мощному развитию Тувы.

Дандар-оол Кок-Хунааевич Ооржак начал свое выступление со слов, что 7 ноября был и останется для страны историческим днем. По его мнению, Октябрьская революция сыграла великую роль в жизни Тувы. Тувинцев, напомнил он, было всего 40-50 тысяч человек. «Как такой малочисленный народ, окруженный такими соседями, как Китай, Монголия и Россия, смог стать в то время отдельным государством?», - спросил Д. К.-Х. Ооржак. И сам же ответил на свой вопрос: «Это стало возможным только благодаря Великой Октябрьской революции!»

Он упомянул о том, что сегодня среди некоторых ученых Тувы есть стремление очернить не только события прошлых лет, но и бросить тень на известных советских ученых Тувы, таких, как Юрий Лудужапович Аранчын. Выступающий попросил не делать этого. И добавил: «Наш маленький народ был неизвестен миру. Благодаря Великой Октябрьской революции образовалось первое суверенное государство тувинского народа и наши отцы, мы все - получили образование».

Григорий Чоодуевич Ширшин поддержал предыдущего выступавшего и еще раз заострил внимание присутствовавших на важности для тувинцев факта государствообразования в 1921 г. «Тувинская Народная Республика, по существу, по форме и по содержанию появилась только благодаря национально-освобо- 
дительной идее Октябрьской революции», - подчеркнул он. Григорий Чоодуевич Ширшин обратился ко всем с просьбой помнить свою историю и подумать над тем, как в дальнейшем развивать свою республику.

Также выступил Константин Борисович Балчий-оол, государственный политический деятель, председатель Законодательной палаты Великого Хурала Республики Тыва (2009-2010), председатель Комитета по общественной безопасности и приграничным вопросам Верховного Хурала Республики Тыва (2010-2014), ныне пенсионер. Он отметил, что в юности был разнорабочим Балгазынского лесхоза, но получил бесплатное высшее образование и достиг больших успехов на муниципальной и государственной службе только благодаря возможностям, которые ему дали Советское государство, Коммунистическая партия. Он напомнил о том, как запускалась вторая очередь комбината Туваасбест в городе Ак-Довураке, строилась Байкало-Амурская магистраль, в строительстве которой также принимали участие тувинские ребята. Достижения страны были очевидны. Все блага, которыми пользуются сегодня граждане страны, были созданы нашими родителями, отцами и дедами.

Иван Васильевич Чучев, депутат Верховного Хурала (парламента) Республики Тыва, от имени депутатов Верховного Хурала, значение Октябрьской революции также оценил сквозь призму своей жизни. В свое время ему молодому человеку, оставшемуся без родителей, доверили новый трактор, научили работать. И это доверие он оправдал. В 1962 году получил награду за поднятие целины.

\section{История в оценках ученых}

После поздравлений ветеранов на круглом столе выступили с докладами ученые.

Название доклада главного научного сотрудника сектора истории Тувинского института гуманитарных и прикладных социально-экономических исследований, доктора исторических наук Николая Михайловича Моллерова звучало так: «О концепции народной революции в Туве».

Моллеров подчеркнул, что коренное население Тувы Советов не создавало и за их власть не выступало. При этом влияние октябрьских событий в России не вызвало в тувинском обществе гражданского раскола и острого межклассового противостояния. Историк считает, что концепция тувинской революции 19171921 гг. была получена, главным образом, способом трафаретного наложения марксистской теории классовой борьбы и учения о социальной революции на действительность традиционной кочевой Тувы. Народная революция предполагает массовое участие в ней народа, но этого, по его мнению, в период 19171921 гг. как раз и не наблюдается. Очевидно, что в событиях августа 1921 г., 
когда было создано первое в истории тувинское государство, решающую роль сыграли не революционные араты, а правящая элита, нойоны и чиновники.

Анализируя события этого периода, Н. М. Моллеров видит, что подавляющая часть тувинских аратов в это время, как правило, поддерживала своих нойонов и чиновников. Свою концепцию он подкрепил новыми фактами, впервые приведенными Ю. Л. Аранчыном, согласно которым, правом решающего голоса на Великом учредительном хурале пользовались 6 удельных князей, 6 помощников князей, 46 чиновников и только 6 аратов. В состав правительства во главе с амбын-нойоном были избраны 5 князей и 2 крупных чиновника.

Большой интерес участников круглого стола вызвало выступление молодого сотрудника сектора истории Тувинского института гуманитарных и прикладных социально-экономических исследований Антона Анатольевича Асонычева, в котором он попытался раскрыть тему Октябрьской революции и двух исторических путей Тувы. По его мнению, благодаря революции за первую половину XX в. наша республика сумела пройти сразу два исторических этапа, тесно связанных с Россией: этап независимого государства, официально провозглашенного на Всетувинском учредительном хурале, состоявшемся 13-16 августа 1921 года, активно ею поддерживаемого, и вхождение в состав России.

Мая Салчаковна Маaдыр, заведующая научной библиотекой Научно-исследовательского института медико-социальных проблем Республики Тыва (НИИ МСПУ РТ) выступила на тему: «Охрана здоровья населения Тувы (19172017 гг.)». Она отметила, что исконно тувинцы располагали богатым опытом народной и традиционной медицины. После Октябрьской революции 1917 г. на территории русских поселений Тувы активизировалось развертывание медицинских пунктов и амбулаторий. В ТНР в 1921 г. охрана здоровья населения стала государственным делом. В Кызыле даже были две клиники - европейская и тибетская. Это наблюдал австриец Отто Менхен-Хельфен, посетивший Туву в 1928 г. После работы советской медико-санитарной экспедиции Наркомздрава РСФСР на территории Тувы в 1928 г. были открыты медпункты, врачебные амбулатории, больницы, дошкольные учреждения. Советское здравоохранение большое внимание уделяло питанию детей, которое способствовало эффективному лечению. Обязательным направлением было систематическое проведение профилактических осмотров тружеников села.

Указанные меры сыграли большую роль в сокращении смертности, росте рождаемости и численности населения Тувы. В настоящее время традиционная медицина получила новый импульс развития. Признано, что союз традиционной и научной медицины открывает перед человечеством широкие перспективы лечения и предупреждения болезней. В республике открыт Центр народной медицины при НИИ МСПУ РТ.

Нелли Хургул-ооловна Наныкпан, заместитель директора Национальной библиотеки им. А. С. Пушкина по научной и издательской работе, выступила с докла190 
дом «Развитие библиотечного дела в Республике Тыва (1915-1917 гг.). Она сообщила, что библиотечное дело в Туве начинает свою историю с 1915 г., с первой приходской общедоступной народной библиотеки в русском поселении - Туране, открытой священником туранской церкви св. Иннокентия отцом Владимиром Юневичем. Вскоре библиотеки были открыты в поселке Уюк и еще на трех зимниках: Бегрединском, Туранском и Тапсинском. В годы советской власти правительством были приняты серьезные меры по ликвидации неграмотности и малограмотности: было введено всеобщее, обязательное начальное образование. Издательским отделом (ТувГИЗ), созданном в 1930 г., начато издание необходимой учебной и массовой литературы, создана система распространения книг.

Директор Института развития национальной школы Республики Тыва, кандидат педагогических наук Алефтина Сугдуровна Шаалы в своем выступлении на тему «Образование в Туве: становление, пути и перспективы развития» сообщила, что становление государственной системы образования в Туве берет свой отсчет с октября 1923 г., когда ЦК ТНРП приняло постановление об обучении молодежи русской и монгольской грамоте, подготовке кадров для работы во всех сферах деятельности молодого государства. С декабря 1924 г. началась работа по обучению народогвардейцев по месту службы. Было принято решение организовать базовую школу в Кызыле, а в сельских местностях - ее отделения. Постановлением ЦК ТАРП в марте 1925 г. при МВД ТНР был организован отдел народного образования. В 1927 г. открылась первая тувинская школа современная школа № 2 города Кызыла. В 1929 г. в республике насчитывалось всего три светских школы. По мнению А. С. Шаалы, прорывным в деле народного просвещения стало появление тувинской национальной письменности. В октябре 1925 г. на IV съезде THРП обсудили вопрос создания тувинской письменности на основе русского алфавита. Автором действующего алфавита на русской графической основе, принятом в 1941 г., является А. А. Пальмбах. Вопросами языка и письменности занимался созданный в 1941 г. Комитет науки. В этом же году было принято решение о переводе тувинской письменности на кириллицу, который был завершен в 1943-1944 уч. г. В 1945 г. были открыты Тувинский научно-исследовательский институт языка, литературы и истории (ныне - Тувинский институт гуманитарных и прикладных социально-экономических исследований) и Кызылское педагогическое училище, в 1946 году Институт усовершенствования учителей, в 1952 году - Кызылский учительский (через 4 года педагогический) институт.

Об «Истории развития архивной службы Тувы» рассказала начальник Отдела комплектования ведомственных архивов и делопроизводства Государственного архива Республики Тыва Белекмаа Юрьевна Сандак. По ее подсчетам, истоки развития архивного дела в Туве берут начало в 1930 г., когда 23 июня Постановлением Агитпропотдела Центрального комитета Тувинской Народно-Революционной партии (ЦК ТНРП) был создан Ученый комитет и при нем Государственный архив. Решением президиума Ученого комитета в августе 1930 г. 
государственным и общественным организациям г. Кызыла и хошунов было предложено в месячный срок сдать материалы двухлетней давности. После создания в марте 1943 г. Научно-исторического архива ТНР и хошунных архивных учреждений началась систематическая концентрация и учет документальных материалов. Новый этап в развитии архивного дела был связан с вхождением ТНР в состав СССР в 1944 г.

Заведующая сектором литературы Тувинского института гуманитарных и прикладных социально-экономических исследований, кандидат филологических наук Уран Алдын-ооловна Донгак в своем выступлении: «Темы Ленина и Октября как культурные каноны соцреалистического искусства в тувинской литературе» сообщила, что ленинско-сталинское вероучение требовало соблюдений культурных канонов. По ее мнению, тувинская поэзия начального периода истории национальной литературы и последующего ее развития отражала главный принцип изображения соцреалистического искусства. С другой стороны, отметила она, тувинская литература в годы своего становления в условиях соцреализма еще не отделилась от синкретичного искусства, где слово и ритуал (обряд) едины в своем проявлении. Под давлением художественных принципов социалистического реализма, тувинская литература задержалась на синкретичном, традиционалистском этапе литературного развития, и вполне обоснованным является определение ее ведущими исследователями литератур народов Сибири (С. Ж. Балдановым и др.) как литературы фольклорного типа. Этим объясняется «ускоренное развитие» т. н. младописьменных литератур в составе советской многонациональной литературы. С этих позиций становится понятным и вполне приемлемым тезис о том, что в рамках соцреализма были созданы лучшие произведения тувинской литературы.

В условиях тоталитарного искусства, в жестких рамках соцреализма писатель, подчиняясь требованиям идеологического контроля, цензуры, тем не менее, как настоящий художник, не в силах был полностью подавлять творческий импульс, свободу самовыражения. Самоцензура, «внутренний редактор» приводили к двоемыслию, когда писатель ограничивал свободу самовыражения. В то же время существование «самоцензуры», внутреннего редактора, вынуждало искать другие выходы авторского самовыражения и возникало такое качество художественного текста, как двуслойность, тайный смысл, скрытый в сюжете, аллегории и т. д.

Заведующая сектором фольклора Тувинского института гуманитарных и прикладных социально-экономических исследований, кандидат педагогических наук Маргарита Базыр-ооловна Кунгаа свое выступление по теме «Отражение идей и событий революции в тувинском фольклоре» начала с вопроса о том, как Советский Союз мог распасться. «Распад страны в 1991 г. вызвал шок, который по сей день отзывается в душе болью», - сказала она. Ученая рассказала о том, что ее родители - чабаны, животноводы - поверили и приняли идеи 
Социалистической революции без всякой боязни. Их симпатия к событию, также, как и народное отношение в целом, выразились в фольклоре, в народных песнях и частушках. В этом жанре многие произведения были посвящены светлому образу Ленина - спасителю, освободителю тувинского народа. Историко-революционный тувинский фольклор заложил основу для возникновения тувинской поэзии и гражданской лирики. Поэтому значение Октябрьской революции будет волновать еще многие поколения ученых, считает она.

Заместитель директора по научно-методической работе Кызылского колледжа искусств им. А. Б. Чыргал-оола, кандидат культурологии Ирина Олеговна Ондар свое выступление назвала «От шаманской пляски до балетного спектакля». По ее мнению, тувинский народ прошел большой исторический путь до развития профессионального искусства: от наскальных рисунков до скульптуры малой формы, от обрядовых охотничьих песен до симфонической музыки, от богатырского эпоса до письменной литературы, от шаманских плясок до балетного спектакля. Для многих народов мира традиционный танец - неотъемлемая часть духовной культуры, в котором находят свое отражение мировоззренческие представления, идеалы народа, его история, жизненный уклад, нравы и обычаи. Особенностью тувинской культуры является тот факт, что к началу XX столетия сведений о народных (бытовых) танцах тувинцев не сохранилось, что подтверждается и отсутствием в словарном корпусе тувинского языка эквивалента слову с прямым значением «танец». Сегодня же тувинский танец прочно занял свое место в современной культуре Тувы, будучи представлен различными видами и жанрами.

Преподаватель информационно-библиотечных и естественно-научных дисциплин Кызылского колледжа искусств им. А. Б. Чыргал-оола Ирина Bumaльевна Подик выступила на тему: «От листов “каменной книги” до современного читателя Тувы». Она отметила, что формирование книжной культуры в Туве имеет свою специфику, значительно отличающуюся от Европейской части России. В Туве существуют свидетельства, подтверждающие наличие письменности, древние каменные стелы с руническими надписями, надписи на каменных плитах, входящих в комплекс погребальных сооружений разных исторических деятелей. Что стало причиной утери высшего достижения местной культуры письменности, сложно судить, но вместе с ней исчезли зачатки книжности. Однако память народа сохраняется в его устном народном творчестве, его фольклоре, в котором можно встретить свидетельства о существовании письменности, книг, бумаги, переводчиков, писцов и уважительного отношения к грамотным.

Она напомнила о том, что весомый вклад в просвещение населения Тувы и приобщению к чтению внесли миссионеры. Священник В. А. Юневич открыл первую библиотеку-читальню в Туране в 1915 г. Библиотека одновременно выполняла функции школы, которую посещали не только русские, но и тувинские дети, что способствовало приобщению их к русской литературе. Русская 
самоуправляющаяся трудовая колония в Туве (РСТК) располагала собственной газетой, типографией, школами и вела большую культурно-просветительскую работу через избы-читальни, клубы и красные уголки, которые были доступны не только русскому, но и тувинскому населению. В 1930 г. по инициативе экспедиции Л. Д. Покровского в Туве был организован Ученый комитет, который принял резолюцию о государственной библиотеке, государственном музее и государственном архиве. В результате в 1931 г. была открыта Кызылская городская, ныне - Национальная библиотека имени А. С. Пушкина.

\section{Заключение}

Круглый стол «Октябрьская революция и Тува», собравший и ученых-тувиноведов, и ветеранов труда, которые выступили свидетелями обсуждавшегося периода истории, позволил обсудить разные аспекты истории Тувы. Самым важным результатом научного и общественно-политического собрания республики стало понимание, что ученые и общественность Тувы солидарны в мнении: Великая Октябрьская революция 1917 года, которая произошла в России, повлияла самым непосредственным образом на исторические события и в Туве, стала фактором дальнейшего слияния исторических судеб маленькой республики и северной державы. И, несмотря на освобождение от идеологического диктата для ученых умов, позитивное значение советской революции для истории Тувы и ее населения мало кем подвергается сомнению в научном сообществе Тувы.

Дата поступления: 15.11.2017 2.

\section{Для циитирования:}

Ховалыг Н. К.-К., Шой-Сюрюн Т. М. Круглый стол «Октябрьская революция и Тува» (г. Кызыл, 7 ноября 2017 г.) [Электронный ресурс] // Новые исследования Тувы. 2017, № 4. URL: https://nit.tuva.asia/nit/article/view/748 (дата обращения: дд.мм.гг.). DOI: $10.25178 /$ nit.2017.4.12

\section{For citation:}

Hovalyg N. K.-K., Shoi-Syuryun T. M. "October Revolution and Tuva”: a Roundtable (Kyzyl, 7 November 2017). The New Research of Tuva, 2017, no. 4 [on-line] Available at: https://nit.tuva.asia/nit/article/view/748 (accessed: ...). DOI: 10.25178/nit.2017.4.12 